\title{
International Diversification And The Cost Of Capital: Is More Necessarily Better?
}

\author{
Darryl G. Waldron, (Email: dwaldron@trinity.edu), Trinity University
}

\begin{abstract}
This study examines the extent to which international diversification is a statistically significant predictor of the cost of capital among S\&P 500 firms. Existing research concerning the "diversification discount" suggests that the financial markets have become enamored with the idea that more tightly focused firms tend to be more profitable and, as a consequence, worth more. Of interest here is the extent to which this same line of reasoning (i.e., less diversification is better) holds for international diversification. The argument put forth here is that while international diversification may indeed be an avenue to higher sales and earnings, this may not be enough to enhance the market value of the firm because unless the additional profit yields a return on invested capital above the firm's cost of capital, and unless that margin is adequate to satisfy existing investors and to attract new capital, the market value of the firm will decline. To fully understand the likely consequences of broader international diversification or, correspondingly, a tighter strategic focus, one must understand how such diversification is apt to affect the firm's cost of capital. This study uses Herfindahl's index of concentration to measure the degree of international diversification among the $S \& P 500$ firms and this measure is subsequently regressed on the cost of capital. What distinguishes this research is its focus on the relationship between a firm's level of international diversification and its cost of capital, a strategically important construct that has been virtually ignored in the literature.
\end{abstract}

\section{INTRODUCTION}

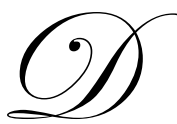

iversification has attracted considerable attention among scholars interested in both its financial and strategic consequences. A review of the literature makes it abundantly clear that among these scholars, business diversification or what Bodner, Tang, and Weintrop (2003) describe as "industrial diversification," has attracted far greater attention than international diversification or what others describe as "global" (Denis, Denis, and Yost, 2000), "geographical" (Geringer, Beamish and da Costa, 1989: Kim, Hwang and Burgers, 1989, 1993) or "market diversification" (Waldron, 2005). Iskandar-Datta and McLaughlin (2005) point out that while the abundance of literature pertaining to industrial diversification has made a valuable contribution to understanding diversification generally, a dearth of research characterizes the study of geographical/global diversification. More specifically, this imbalance has produced a wealth of research dealing with the relationship between industrial diversification, financial performance, corporate strategy, and the creation of shareholder value. However, the literature related to international diversification and its relationship to financial performance and the creation of shareholder value remains less well developed. As a result, many misunderstandings exist regarding the potential benefits and limitations of international diversification, with both managers and investors left to believe that on balance, international diversification is inherently good and that it is indeed an avenue to better financial performance and, correspondingly, growth in shareholder value. Not surprisingly, a number of theories of international diversification exist that tend to reinforce this line of reasoning.

The theory that international diversification is fundamentally a risk reduction strategy emanates from, and is largely explained in terms of, the theory of financial portfolio theory (Kim, et al., 1998), which argues that investment in an array of financial assets whose returns are uncorrelated will reduce the firm's risk at any level of return (Markowitz, 1959). Whether the firm is likely to be able to parlay geographical diversification into improvements in market value would appear to depend on management's ability to achieve higher risk adjusted returns operating on 
behalf of shareholders than shareholders can achieve through their own portfolios. Given the ease with which shareholders are now able to achieve high levels of international diversification on their own, one might reasonably question why they would pay an agent a premium for a service of dubious value. In fact, Jacquillat and Solnik (1978) found that compared to a portfolio of U.S. domestic shares, the reduction in risk achieved by investing in the shares of a portfolio of U.S. multinationals amounted to 10 percent while investment in an internationally diversified portfolio of stocks reduced risk 50 to 70 percent. Nevertheless, there is some evidence that risk diversification can be achieved by carefully balancing the size and location of specific projects, and by creating an optimal mosaic of countries whose business cycles are uncorrelated with the cycle of the home country (Levy and Sarnat, 1970). When viewed in practical terms, however, achieving this kind of "balance" would be extraordinarily difficult and, in many instances, imprudent.

The theory that international diversification is an avenue to achieving higher returns to scale and scope has its origin in international economics and the theory of foreign direct investment (resource based theory of the firm). Enhanced value derives from management's ability to assemble an array of firm specific, tangible, and intangible assets whose output can be sold across more markets and whose largely fixed costs can, as a consequence, be amortized over more output. Firms undertake international investment because no external markets exist for these assets that would yield a return commensurate with their "internal value" (Caves 1971: Hymer, 1976). Closely related in principle to the scale theory of international diversification, the transaction costs theory suggests that multinational firms do not expand abroad to reduce risk, but to internalize markets for intermediate inputs like raw materials, brand equity, advertising, knowledge, and research. Considerable empirical evidence exists to support the transaction costs theory (Morck and Yeung, 1991, 1997).

Real options theory (Amram and Kulatilaka, 1999) has provided a basis for explaining international diversification, where higher returns to broader geographical diversification derive from the advantages multiple markets, production sites, and a more varied set of market imperfections provide. In this regard, Kim, Hwang, and Burgers (1989) demonstrated that because of the options that international diversification provides, firms that are highly diversified geographically enjoy consistently higher returns than their less diversified brethren. Errunza and Senbet $(1981 ; 1984)$ suggest that an internationally diversified firm also creates higher incremental value through an enhanced ability to arbitrage regulatory differences in taxation and finance. The presence of market imperfections appear to allow firms that are better managed, quicker to respond to emerging opportunities and change, and more flexible to take extract more by way of gains in market share from more markets. Kogut (1983) addresses these valuecreating capabilities that attach to international diversification in terms of "operational flexibility." And, as Bodnar, Tang and Weintrop (2003) point out:

In light of the increasing uncertainty of the international environment, an internationally diversified network gives the firm the opportunity to exploit market conditions. For example, a multinational production network allows shifting of production in response to any large-scale changes in relative prices that can occur internationally. This cost structure flexibility helps reduce the average marginal cost of worldwide production relative to that of purely domestic production and results in higher profit margins or greater market share. A similar argument holds for average output prices across foreign markets when demand shocks are not perfectly correlated. Conditional on the costs of creating and maintaining a corporate network that is diversified across international-based uncertainties and the variability of the relative prices, such a network can add additional value to the firm because of ability to exploit a larger variety of market conditions (p.5).

Viewed more broadly, diversification has generally been thought of in terms of the extent to which a firm is engaged in related business activities. In fact, Rumelt's (1974) early research pertaining to diversification developed the notion of "relatedness" around the classification of firms into four groups: "single-business" firms where more than 95 percent of a firm's revenue is derived from a single activity or product line, "dominant-business" firms with between 70 and 95 percent of revenue coming from a single activity or product line, related-business firms where less than 70 percent of revenue is derived from a single activity or product line but where its other lines are closely related to its primary activity, and "unrelated-business" firms where less than 70 percent of revenue is derived from a single activity or line and where other revenue comes from unrelated activities or lines. To accommodate the research undertaken here, Rumelt's (1974) classification scheme was adapted to "measure" the extent of market diversification 
characteristic of S\&P 500 firms, where a "single-market" business was defined as one that derives more than 95 percent of its revenue from one market, a "dominant markets" business derives between 70 and 95 percent of its revenue from a few core markets, and a "diverse markets" business is one that derives less than 70 percent of its revenue from a few core markets. Admittedly, this adaptation was based on the researcher's judgment, but it took into consideration past criticisms of Rumelt's model (Dess, Gupta, Hennart, and Hill, 1995), as well as the alternative U.S. Justice Department's scheme, which tends to overweight the impact of very modest increases in market concentration (U.S. Department of Justice and the Federal Trade Commission. See Merger Guidelines § 1.51.).

Again, most of the research pertaining to diversification has concentrated on business diversification and its relationship to enhanced financial performance, largely ignoring market diversification or considering it apart from business diversification. Nevertheless, some researchers have used the business diversification paradigm to explore the extent to which broader international diversification is likely to result in improved financial performance, research that is touched on in the review or the literature. The research undertaken here treats international diversification among the S\&P 500 firms as a two-dimensional consideration, one being the direct consequences of greater geographical diversity and the other the indirect consequences of the interaction of geographical diversification and business diversification. The level of both international and business diversification was measured using the Herfindahl index (Herfindahl, 1950), sometimes referred to as the Herfindahl-Hirshman index $(H H I)$, where the percentages of total revenue generated by each geographical market and business segment were squared and summed to derive measures of international diversification $\left(H H I_{m}\right)$ and business diversification $\left(H H I_{b}\right)$. The presence of a statistically significant interactive effect was subsequently tested for by deriving the multiple for international and business diversification $\left[\left(H_{H} I_{m}\right)\left(H H I_{b}\right)\right]$, a well-documented procedure (Geringer, Tallman and Olsen, 2000). Correspondingly, use of the Herfindahl index to measure diversification is also well documented in the literature (Comment and Jarrell, 1995; Berger and Ofek, 1995; John and Ofek, 1995).

Of interest where the research being undertaken here is concerned is the extent to which international diversification and the interactive effect of international and business diversification, are likely to raise or lower a firm's cost of capital, a broadly recognized determinant of shareholder value (Rappaport, 1998; Ehrhardt, 1994; and Copeland, Koller and Murrin, 2000). In this regard, Lamont and Polk (2000) underscore the potential importance of the cost of capital as a determinant of value in their examination of the relationship between diversification and the destruction of shareholder value:

Most existing empirical work has focused on potential cash flow effects of diversification (for example, studies of profits or productivity in diversified firms). One could also imagine discount rate versions of existing explanations. For example, perhaps inefficient cross-subsidization involves taking excessively risky projects with high discount rates (p. 6).

The underlying premise of the research conducted here is that international diversification that results in even significant increases in revenue, earnings and cash flow will only lead to the creation of shareholder value if the resulting return on invested capital exceeds the firm's cost of capital adjusted for diversification related risk. In this regard, there is considerable evidence to suggest that diversification perceived by investors to be taking the firm away from its core market or core business, thereby compromising the firm's strategic focus, is likely to erode shareholder value. As Rappaport (1998) points out, "It is well established that management creates value when corporate investments in plant and equipment, working capital, and research and development are made above the marketrequired rate of return, that is, the cost of capital." Diversification that is not expected to earn a rate of return above the firm's risk adjusted cost of capital will see its share price bid down even though sales, earnings, and cash flow may rise. Correspondingly, one would expect diversification undertaken at what investors judge to be a reasonable cost, where synergy is likely to result and the same effect cannot be achieved by investors acting independently, and where it is highly likely that the resulting return on invested capital will exceed the market's required rate of return, resulting in an increase in the firm's market value. Otherwise, the firm is likely to see its cost of capital bid up and, unless this increase is offset by higher returns, a challenge likely to be made more difficult when diversification takes the firm away from markets and activities where it has a competitive advantage, the underlying economic value of the firm will decline with market value likely to follow. 
Given the importance of the relationship among diversification, the cost of capital and market value, it is difficult to understand why, as Lamont and Polk (2000) point out, most related empirical research has focused on the cash flow effects of diversification in the form of earnings and productivity, completely ignoring the cost of capital. The purpose of the research undertaken here was to remedy this oversight by measuring the extent to which a tighter strategic focus, achieved through less international diversification, tends to be associated with a lower cost of capital. Put otherwise, this research tests the following hypotheses:

$\mathbf{H}_{1}$ : $\quad$ There is not a statistically significant relationship between levels of international diversification and a firm's cost of capital.

$\mathbf{H}_{2}$ : There is not a statistically significant relationship between the interactive effect of business and market diversification and a firm's cost of capital.

\section{REVIEW OF THE LITERATURE}

The empirical literature pertaining to diversification and the relationship between diversification and the creation of shareholder value has developed largely along two streams: one that has focused on diversification's affect on various measures of financial performance and a second that has focused on the direct response of financial markets to management's decision to diversify, broadly referred to as the diversification discount literature. The extent to which diversification is viewed as a strategy for creating shareholder value has changed significantly over the past two or three decades. Matsusaka (1993), Elgers and Clark (1980), Polk (1999), and Hubbard and Palia (1999) discovered that companies that undertook diversification during the 1960s and 1970s experienced positive abnormal financial returns and, in turn, corresponding increases in market value. Kline (1997) found that U.S. conglomerates traded at a significant premium to more tightly focused single business firms during the late 1960s. When operating efficiency and leverage were controlled for, this premium rose to 19 percent. When viewed over time, however, what was a premium turned into a discount of 21 percent for the period 1966-72, growing to a discount of 36 percent from 1969-72. Nevertheless, as Ravenscraft and Scherer (1987) point out in their study of 471 manufacturing companies, firms of every size operated in many more markets in 1975 than they had 25 years earlier. Not surprisingly, this diversification movement spawned various theories purporting to account for the potential benefits of diversification (see the earlier discussion of theories of international diversification), including benefits derived from the more efficient allocation of resources through internal capital markets, benefits resulting from the broader and more efficient allocation of fixed investment, tax benefits obtaining from the ability to offset business unit losses against firm gains, and arbitrage opportunities based on tax and regulatory differences among international markets (Berlin, 1999; Harris and Raviv, 1996; Hubbard and Palia, 1998; and Montgomery and Wernerfelt, 1998).

The notion that conglomerate diversification contributed to enhanced financial performance and to the creation of shareholder value was challenged during the 1980s and 1990s by research suggesting that such diversification actually contributed to the erosion of profitability and shareholder value. Daley, Mehrotra, and Sivakumar (1997) considered the post spin-off performance of 212 firms from 1975 to 1991 and determined that operating performance of the parent companies improved where the asset spun off was in an unrelated business, thus leaving behind a more tightly focused parent. Ramanujam and Varadarajan (1989) and Montgomery (1994) found that unrelated diversification tended to compromise financial performance over a cross-section of businesses, markets, and industries. A number of other scholars including Rumelt (1982), Bhagat, Shleifer and Vishny (1990), Jensen (1989), and Kaplan and Weisbach (1992) also argue that unrelated diversification contributed little to the creation of shareholder value during the conglomeration movement of the 1960s and 1970s and set the stage for the corporate restructuring movement of the 1980s and 1990s. What is less well understood is just what precipitated the subsequent shift in thinking among shareholders and, in turn, management with respect to the virtues of strategic focus as opposed to the virtues of unrelated diversification. Perhaps Berlin (1990), building on the work of Kline (1997), Servaes (1996), Matsusaka (1996), Ravenscraft and Scherer (1987), and Liebeskind, Opler and Hatfield (1996), best describes the historical pattern in thinking regarding the virtues of diversification when he suggests that the behavior of the diversification discount, particularly its behavior during the 1970s, is a puzzle.

Nevertheless, a preponderance of the evidence from the 1980s and 1990s supports the presence of a change in thinking among market participants regarding the virtues of diversification and their adoption of the mantra of 
strategic focus. John and Ofek (1994) and Berger and Ofek (1995) acknowledge this change in market sentiment in their frequently cited examination of the diversification discount. Using an approach employed earlier by LeBaron and Speidell (1987), Berger and Ofek (1995) went on to estimate diversification's effect on firm value by comparing the existing value of the firm with its imputed break-up value to derive an implied cost of diversification of 13-15 percent among a cross-section of firms for the period 1986-1991. They attribute the loss in value to the degree of relatedness, overinvestment in marginal opportunities and cross-subsidization of weak business units. In subsequent research, Berger and Ofek (1996) found that firms trading at higher discounts were significantly more likely to undertake restructuring efforts aimed at achieving greater strategic focus.

Wernerfelt and Montgomery (1988) and Lang and Stulz (1994) discovered the presence of an inverse relationship between greater diversification and the creation of shareholder value that persisted throughout the 1980s. Comment and Jarrell (1995), in their examination of approximately 2000 firms over the period 1978-1989, found that an increase in strategic focus measured using the Herfindahl index for both revenue and assets produced increases in shareholder value of 4.3 percent on revenue and 3.5 percent on assets. A number of additional studies (Kaplan and Weisbach, 1992; Gertner, Powers and Scharfstein, 1999; Berger and Ofek, 1999; Schlingemann, Stultz and Walkling, 1999; and Peyer and Shivdasani, 2000) have examined the impetus for and consequences of refocusing on the part of diversified companies, finding that in general diversification tends to destroy shareholder value. Correspondingly, Morck, Shleifer and Vishny (1990), Maquiera, Meggison and Nail (1998) and Schoar (1999) found that acquisitions that compromise strategic focus tend to also compromise productivity and destroy value for shareholders of the acquiring firm. Campa and Kedia (2002) argue that although diversified firms trade at a discount relatively to similar single-segment firms, whether a diversified firm trades at a discount or a premium is a function of endogenous factors, not the decision to diversify. Villalonga (2000) found that when one adjusts for industry differences that encourage/discourage diversification, any diversification discount disappears and is replaced by a statistically significant diversification premium. In their examination of financial conglomerates, Laeven and Levine (2004) determined that firms engaged in multiple activities tend to trade at a discount to firms engaged in individual activities lending support to the proposition that business diversification tends to erode shareholder value.

A review of the empirical literature on diversification suggests that far less attention has been paid to market (geographical) diversification than to business diversification, and no attention has been paid to the relationship between market diversification and the cost of capital. As evidence of this imbalance, Iskandar-Datta and McLaughlin (2005) point out that the literature "exclusively focuses on industrial (i.e., business) diversification with a dearth of research on geographical/global diversification." Again, one of the expressed purposes of the research undertaken here is to address this void in the literature.

In addition to being limited in terms of scale and scope, Iskandar-Datta and McLaughlin (2005) also argue that research devoted to market diversification has left many questions unanswered: "Not unlike the research on industrial diversification, the research in this area also produces inconclusive results." In this regard, Morck and Yeung (1991) found that "multinationality" has no significant impact on shareholder value while Denis, Denis and Yost (2002) provide evidence to suggest that global diversification produces a diversification discount comparable to the discounts associated with business diversification. Christophe (1997) and Christophe and Pfeiffer (1998) also identified an inverse relationship between global diversification and the creation of value. Goerzen and Beamish (2003) found that although there was a positive relationship between business diversification and shareholder value, a negative relationship obtained between firm value and market diversification. Correspondingly, Goerzen and Beamish (2003) also found that there was a positive interaction effect between business and market diversification and the creation of shareholder value.

Among those suggesting that broader market (geographical) diversification clearly and unambiguously benefits the firm and its shareholders, Errunza and Senbet $(1981,1984)$ found that "excess value" shared a significant positive relationship with the percentage of sales generated by foreign subsidiaries and that international diversification eliminates barriers to entry that exist for individual investors. Kim and Lyn (1986) subsequently confirmed these results. As an aside, one might imagine that the broader and more open access to foreign markets that exists today would mitigate against the barrier to entry effects cited by Errunza and Senbet $(1981,1984)$ and Kim and Lyn (1986). Similar research by Doukas and Travlos (1988) showed that shareholders of U.S. multinationals that 
enter new foreign markets experience statistically significant gains. Iskandar-Datta and McLaughlin (2005) found that globally diversified firms significantly outperform more focused firms on a variety of financial measures and that such global diversification does not result in the misallocation of capital and, thus, is entirely consistent with the principle of maximizing shareholder value. Mathur, Singh, and Gleason (2004) provide evidence suggesting that multinational firms outperform purely domestic and exporting firms and that the degree of diversification is "strongly related to superior financial performance." Finally, Bodnar, Tang, and Weintrop (2003) put the effect of international diversification on shareholder value in more precise terms, arguing that an international diversification premium of approximately 1.4 percent attaches to higher levels of market diversification.

In summary, empirical research examining the relationship between international diversification and the creation of shareholder value, as well as research pertaining to the interaction of international and business diversification and the creation of shareholder value, has produced mixed results that could best be described as inconclusive. In some instances statistically significant evidence has been presented of a diversification discount in association with both business and market diversification. In other instances there has been evidence of a diversification premium. Still other research has associated discounts and premiums with the "relatedness" of the diversification effort with greater relatedness creating and less relatedness destroying shareholder value. Various financial metrics have been utilized as predictor variables with an emphasis placed on different accounting based measures of profitability and their apparent relationship to the value of the firm. What the literature has ignored, however, is the underlying process by which investor sentiment regarding market diversification is translated into an increase or a decrease in shareholder value, a process that can not be effectively assessed if one relies on accounting based measures of performance (Rappaport, 1986), and one shortcoming that the current research addresses. Furthermore, existing research has focused on the cash flow effects of diversification measured in terms of profitability, asset utilization and productivity, completely ignoring the cost of capital, a second shortcoming that the research undertaken here addresses (Lamont and Polk, 2000).

\section{RESEARCH DESIGN AND METHODOLOGY}

This study is based on a cross-sectional analysis of the firms comprising the S\&P 500 for the year 2004. The use of S\&P 500 companies systematically eliminated any small-firm effects and industry specific bias, assured sufficient international exposure to produce a robust measure of market diversification, and provided a database of adequate size relative to the number of predictor (independent) variables to be able to rely with confidence on the resulting measures of statistical significance. The data were subjected to a step-wise multiple regression analysis, where the cost of capital $\left(k_{0}\right)$ was treated as a function of the firm's (1) degree of market (geographical) diversification and (2) the combined (interactive) effect of business and market diversification. Again, both business and market diversification were measured using the Herfindahl (1950) index, a frequently utilized measure of diversification (Comment and Jarrell, 1995; Berger and Ofek, 1995; Tallman and Li, 1996; Geringer, Tallman and Olsen, 2000; Grant, Jamminhe and Thomas, 1998; Itami, Kagono, Yoshiharaa and Sakuma, 1982; and Robins and Wiersema, 1995) that, unlike other measures of diversification, simultaneously considers the number of business or market segments in which the firm operates and the relative contribution each segment makes to total revenue. In addition, the Herfindahl index can be used to judge the relative strategic importance of business and market diversification as elements of corporate strategy, where a lower Herfindahl measure would suggest a strategic emphasis on diversification with a higher Herfindahl measure suggesting greater reliance on strategic focus.

The combined effect of business and market diversification was calculated in a manner consistent with the approach utilized by Geringer, Tallman, and Olsen (2000), where business diversification was multiplied by market diversification to derive a combined Herfindahl measure. Empirical studies of the interactive effects on firm performance of business and market diversification have been fairly limited and have in general produced mixed results. Goerzen and Beamish (2003), Christophe (1997), and Christophe and Pfeiffer (1998) identified an inverse relationship between business and market diversification and the creation of shareholder value-as market diversification increased, firm value declined. Geringer, Tallman, and Olsen (2000), like Franko (1989), found no significant interactive effects of business/market diversification on firm performance. Correspondingly, Kim, Hwang and Burgers (1989) found that firms characterized by higher levels of business diversification benefit to a greater extent from increasing market diversification. Although questions have been raised about the specification of their 
regression model, Hitt, Hoskisson and Kim (1997) also identify similar interactive effects with increases in business diversification tending to reduce the negative effects of high levels of market diversification. Geringer, Tallman and Olsen (2000) found that business and market diversification "act simultaneously, but without interaction." An increase or decrease in either business or market diversification does not significantly influence the joint contribution of the two modes of diversification at lower levels, but financial performance tended to decline at higher levels of combined diversity. Broadly interpreted, these results appear to argue for a tighter strategic focus.

The underlying premise of the research being undertaken here embraces the resource-based theory of the firm whereby corporate strategy is committed to taking advantage of scale and scope economies that allow for the broader utilization of core competencies, assets, and technologies. Business and market diversification that can be leveraged for improved performance can be expected to grow value, but excessive diversification, whether it is by business or market, is likely to undermine performance, leading to a decline in the present value of free cash flow to the firm. There are myriad reasons for such declines in performance that tend to be highly firm and situation specific, but the effect is accounted for by an increase in the firm's cost of capital as investors respond to the increased risk that attaches to higher and higher levels of diversification. Put differently, an extremely low combined Herfindahl index would be more likely to translate into a higher cost of capital than would a higher Herfindahl index-investors are inclined to reward a tighter strategic focus and to penalize excessive business/market diversification. Correspondingly, an extremely high combined Herfindahl index (i.e., a strategy based on focus and achieving scale and scope economies) would be more likely to translate into a lower cost of capital.

The procedure employed to derive estimates of market diversification and the interactive effects of business and market diversification may be formally described as follows:

The revenue-based Herfindahl index $\left(H_{H} I_{b}\right)$ measuring business diversification is calculated across $n$ business units as the sum of the squares of each unit's sales, $\mathrm{S}_{\mathrm{bi}}$, as a percentage of total sales:

$H I_{b}=\sum_{i=1}^{n} S_{b i}^{2} /\left(\sum_{i=1}^{n} S_{b i}\right)^{2}$

Correspondingly, the revenue-based Herfindahl index measuring market diversification $\left(H H I_{m}\right)$ is calculated across $n$ market segments as the sum of the squares of each segment's sales, $S_{m i}$, as a percentage of total sales:

$H H I_{m}=\sum_{i=1}^{n} S_{m i}^{2} /\left(\sum_{i=1}^{n} S_{m i}\right)^{2}$ follows:

The presence of an interactive effect between business and market diversification $\left(H H I_{i}\right)$ was measured as

$H H I_{b m}=\sum_{i=1}^{n} S_{b i}^{2} /\left(\sum_{i=1}^{n} S_{b i}\right)^{2} \sum_{i=1}^{n} S_{m i}^{2} /\left(\sum_{i=1}^{n} S_{m i}\right)^{2}$

Estimates of the cost of capital $\left(\mathrm{k}_{0}\right)$, which for purposes of valuation is the appropriate rate for discounting a firm's future free cash flows (Rappaport, 1998), were obtained from ValuePro (www.valuepro.com) and were derived as follows:

$\mathrm{k}_{0}=\mathrm{w}_{\mathrm{i}}\left(\mathrm{k}_{\mathrm{b}}\right)\left(1-\mathrm{t}_{\mathrm{i}}\right)+\mathrm{w}_{\mathrm{e}}\left(\mathrm{k}_{\mathrm{e}}\right)$ 
where:

$\mathrm{W}_{\mathrm{i}}=$ percentage of long-term debt in capital structure

$\mathrm{w}_{\mathrm{e}}=$ percentage of equity in capital structure

$\mathrm{k}_{\mathrm{i}}=$ yield to maturity on long-term debt

$\mathrm{k}_{\mathrm{e}}=$ implicit rate of return required by shareholders (cost of equity)

$t_{i}=$ firm specific marginal rate of taxation

The implicit rate of return required by shareholders $\left(k_{e}\right)$ is estimated by ValuePro using the CAPM, which treats $k_{e}$ as a function of the risk-free rate plus an appropriate equity premium, as follows:

$\mathrm{k}_{\mathrm{e}}=\mathrm{r}_{\mathrm{f}}+\beta_{\mathrm{i}}\left(\mathrm{r}_{\mathrm{m}}-\mathrm{r}_{\mathrm{f}}\right)$

where:

$\mathrm{r}_{\mathrm{f}}=$ yield to maturity on 10 year Treasury bonds

$\mathrm{r}_{\mathrm{m}}=$ market rate of return on equity

$\beta_{\mathrm{i}}=$ firm beta

The nature of the underlying relationship between a firm's cost of capital and the creation of shareholder value is well understood and well documented in the literature: to grow value on a sustained basis the firm must earn a return on invested capital that exceeds its cost of capital and that is sufficient to attract investment capital. What is less well understood is the extent to which international diversification affects this process through its influence on the firm's cost of capital, or the extent to which market and business diversification interact to influence the firm's cost of capital. As suggested earlier, one reason for this lack of understanding is that related empirical research has focused on the earnings and cash flow effects of diversification, completely ignoring the role of the cost of capital (Lamont and Polk, 2000).

Again, the data were subjected to a cross-sectional step-wise multiple regression analysis where the Herfindahl index for market diversification, along with the index for interactivity were regressed on the cost of capital. A firm that is unable to parlay market diversification into a rate of return above the firm's risk adjusted cost of capital will destroy shareholder value even though sales, earnings and cash flow may rise. On the other hand, diversification that yields a return on invested capital above the firm's risk adjusted cost of capital will grow shareholder value. Because of its overriding importance in the shareholder value algorithm, understanding how the cost of capital responds to changes in the level of diversification is fundamentally important in understanding whether diversification is likely to be a value creating or a value destroying strategy, and in understanding the mechanism by which value is likely to be created or destroyed. The research design employed here reflects the narrowly defined objectives of the study and the fact that the diversification literature is replete with investigations of "relatedness," endogenous and exogenous influences, "scope economies," and country, industry, and market specific considerations and their impact on market value. The fully specified regression model appears as follows:

$\mathrm{k}_{0}=\mathrm{a} \pm \beta_{\mathrm{mi}}\left(\mathrm{x}_{\mathrm{mi}}\right) \pm \beta_{\mathrm{bmi}}\left(\mathrm{x}_{\mathrm{bmi}}\right)+\mathrm{e}$

where:

$\beta_{\mathrm{mi}}=$ beta coefficient for market diversification

$\beta_{\mathrm{bmi}}=$ beta coefficient for interactive effects

$\mathrm{x}_{\mathrm{mi}}=$ predictor of market diversification for firm $\mathrm{i}, \mathrm{HHI}_{\mathrm{mi}}$ $\mathrm{x}_{\mathrm{bmi}}=$ predictor of interactive effects for firm $\mathrm{i}, \mathrm{HHI}_{\mathrm{bmi}}$ 
If the financial markets favor strategic focus over diversification, financial theory dictates that one would expect to see a higher Herfindahl index for market diversification associated with a lower cost of capital. Correspondingly, interaction effects between business and market diversification that produce a relatively higher Herfindahl index should also be associated with a lower cost of capital. Under such financial market conditions, theory would also seem to suggest that a firm's cost of capital should follow some orderly progression from a relatively low to a relatively high cost as the degree of business and/or market diversification increases. This analysis explores the underlying nature of the relationship between levels of international diversification and changes in the cost of capital using an modified version of Rumelt's (1974) original classification scheme to define levels of international diversification, making it possible to associate a firm's cost of capital with its level of diversification. Rumelt (1974) classified firms into three groups based on a specialization ratio $\left(R_{S}\right)$, referred to as part of the analysis undertaken here as a dependency ratio $\left(R_{d}\right)$, which he calculated as the proportion of a firm's annual revenue generated by its largest business or market. This ratio served as a measure of the firm's commitment to diversification and the current analysis remains faithful to Rumelt's (1974) proportions.

To accommodate the research undertaken here, Rumelt's (1974) classification scheme was adapted to "measure" the extent of market diversification characteristic of S\&P 500 firms, where a "single-market" business was defined as one that derives more than 95 percent of its revenue from one market, which corresponds to a Herfindahl index above 9025. A "dominant markets" business was defined as one that derives between 70 and 95 percent of its revenue from a few core markets, which corresponds to a Herfindahl index of approximately 4925 to 9025 , and a "diverse markets" business was defined as one that derives less than 70 percent of its revenue from a few core markets, which corresponds to a Herfindahl index of under 4900. Departing to some extent from Rumelt's (1974) format, no attempt was made to distinguish between "related" and "unrelated" diversification, an initiative beyond the scope of this analysis and a topic thoroughly covered in the existing literature. Exhibit 1 applies this modification of Rumelt's (1974) classification scheme to the cost of capital versus level of international diversification problem being analyzed here.

Exhibit 1: Rumelt's Classification Scheme and the Cost of Capital

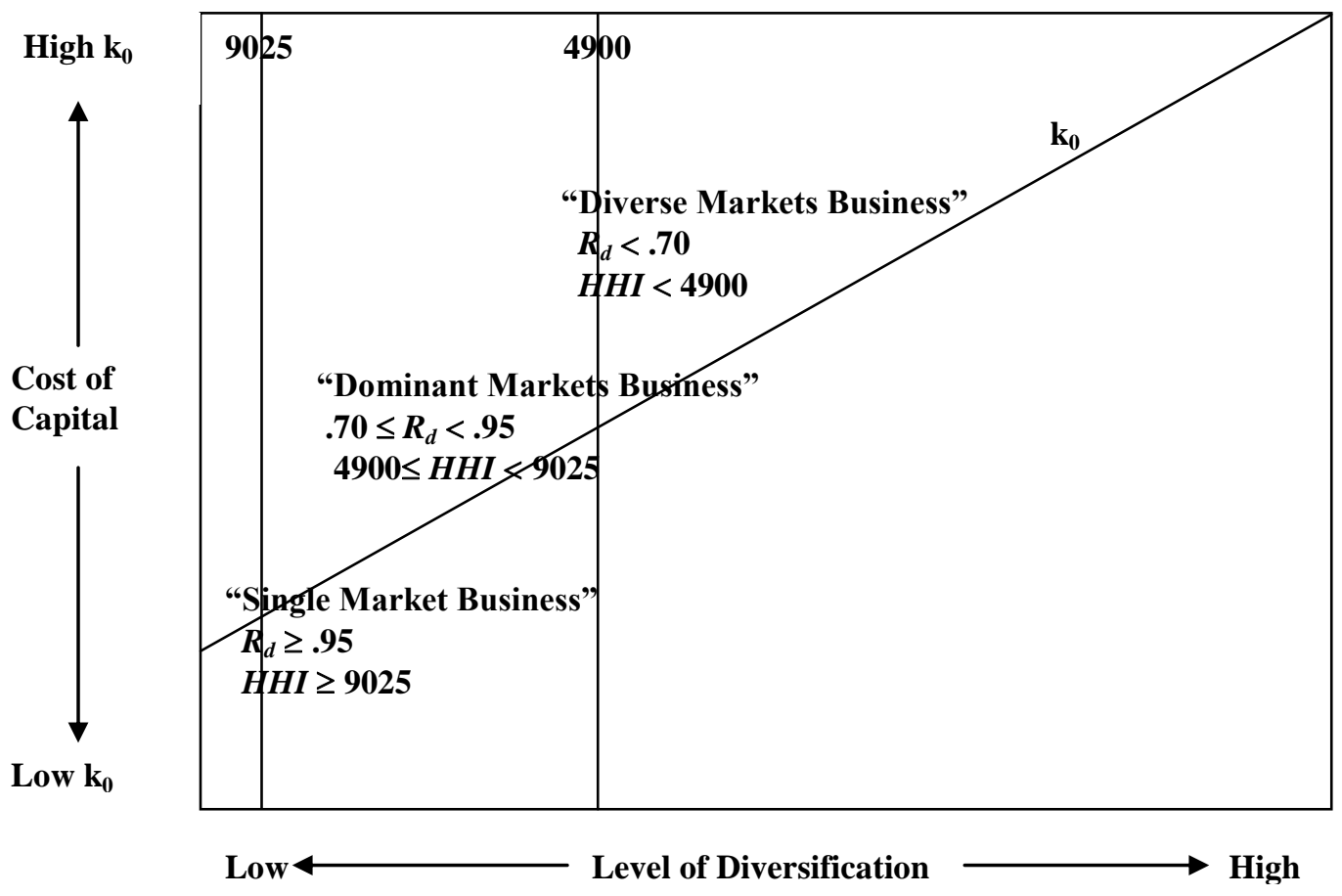


Once again, the premise of this analysis is that greater international diversification is more likely to result in a higher cost of capital. The financial markets, dominated by investors with a preference for strategic focus, with the ability to diversify through their own portfolios and an aversion to complexity, uncertainty, and change are simply acting in their own self-interest when they demand a higher rate of return as compensation for tolerating what they view as a suboptimal strategy. Unless the firm can offset this increase through a higher return on invested capital, management will see the market value of the firm bid down. In the final analysis, diversification strategy is about much more than competing for market share in new businesses and markets, it is also about competing for capital in markets that prefer that a firm keep its strategy simple and straightforward. Of interest here is the extent to which market diversification and the combination of business and international diversification tend to raise or lower a firm's cost of capital. The scope of the study is by design general and is intended to lend itself to the kind of interpretation alluded to by Lindstrom (2005) in his discussion of Rumelt's (1982) analysis of "related" diversification. Here context is not being ignored; for example, it is well understood that technology companies tend to have a higher cost of capital than car companies, and that the risk-free rate, betas and equity premiums are time sensitive. Rather, contextual considerations were "cross-sectionalized" in order to determine whether variation in the cost of capital among S\&P 500 companies supports what seems to be the prevailing wisdom regarding investor preferences (Berlin, 1999): namely, that market participants tend to prefer corporate focus to diversification.

Referring to $\mathrm{H}_{1}$ and $\mathrm{H}_{2}$, if there is no relationship between the level of market diversification or between the combined effect of market and business diversification and the cost of capital, one would have a basis for questioning the extent to which investors consistently prefer strategic focus to diversification. Conversely, if there is a statistically significant relationship between the level of market diversification or between the combined effect of market and business diversification and the cost of capital, and investors do indeed favor focus over diversification, both theory and logic dictate that higher levels of market diversification (i.e., a lower $H H I_{m}$ ) or a higher combined effect (i.e., a lower $H H I_{b m}$ ) would tend to produce a higher cost of capital.

The mean $k_{0}$ for the S\&P 500 firms was 7.69 percent, ranging from a low of 4.53 percent to a high of 12.25 percent. The mean $H H I_{m}$ was 6792 , and the range was 1841 to 10,000 , while the mean $H H I_{b m}$ was approximately .4300 when adjusted to a base of one, with a range of .3321 to 1.00 . Within the context of Rumelt's (1974) classification scheme, the average S\&P 500 firm could best be characterized as a "dominant markets" business. A modest level of diversification among a few "core" markets would characterize such a business. Correspondingly, 35.5 percent of S\&P 500 firms were "single market" businesses and 30.2 percent were "diverse market" businesses. These companies are characterized by a high degree of market diversification and are less dependent on a few core markets than are "dominant market" businesses. At the extremes, 30.0 percent of the firms had a $H H I_{m}$ of 10,000 and only 8.2 percent had a $H H I_{m}$ below 3000, suggesting that a preponderance of S\&P 500 firms could best be characterized as more concentrated or strategically focused than broadly diversified with respect to the geographic markets they compete for. When the average costs of capital for firms comprising the lowest and highest 40 percent of the sample were compared with the corresponding average levels of market diversification and average interactive effect, lower average levels of diversification (i.e., higher average Herfindahl index) were associated with a lower average cost of capital. Alternatively, the group mean cost of capital for more tightly focused firms was 216 basis points below the group mean cost of capital for more internationally diversified firms. Table 1 presents a summary of selected descriptive statistics.

Table 1: Descriptive Statistics

\begin{tabular}{|c|c|c|c|}
\hline Statistics & $\mathbf{k}_{\mathbf{0}}$ & $\mathbf{H H I}_{\mathbf{m}}$ & $\mathbf{H H I}_{\mathbf{b m}}^{\mathbf{1}^{\mathbf{2}}}$ \\
\hline Mean & 7.69 & 6791 & .4300 \\
\hline Std. Error & .0536 & 122.91 & .0113 \\
\hline Median & 7.62 & 6450 & .3413 \\
\hline Std. Deviation & 1.193 & 2715 & .2810 \\
\hline Mean $_{\leq .40}$ & 6.66 & 7810 & .4559 \\
\hline Mean $_{\geq .60}$ & 8.82 & 5878 & .3884 \\
\hline
\end{tabular}

1. Statistics are transformed from a base of 10,000 to a base of 1.00 
Table 2 presents the results of the multiple regression analysis. Here market diversification $\left(H H I_{m}\right)$ and the interactive effect of business and market diversification $\left(H H_{b m}\right)$ were regressed on the cost of capital $\left(k_{0}\right)$ using a stepwise approach. Step-wise multiple regression analysis selects variables for inclusion in the regression model in descending order based on the contribution each makes in explaining overall variance in the dependent variable. Where there is a statistically significant relationship between one or more of the predictor variables and the dependent variable, the standardized regression coefficient(s) can be used to judge which variables (form of diversification) accounts for significant amounts of the variance in the cost of capital and to explain or describe the nature of that variance. While a variety of statistical tests are available to evaluate the explanatory power of the predictor variables, this analysis relied on an $\mathrm{F}$ ratio to enter of .05. Given this criterion, only those variables with a partial $\mathrm{F}$ ratio of .05 or above were selected for inclusion in the model. Under the step-wise regime, the first predictor variable is selected for inclusion based on total variance while the second and subsequent variables are selected for inclusion based on the amount of residual variance explained. An overall $\mathrm{F}$ ratio of .05 was used to judge the statistical significance of the model and the assumption of linearity was tested for and satisfied through diagramming. The sample size was sufficient to produce a ratio of observations to variables well beyond the minimum requirement of at least 10 (Hair, Anderson and Tatham, 1987) and well beyond the minimum of 80 suggested by Tabachnick and Fidell (2001) for a step-wise model consisting of two predictor variables. The resulting Durbin-Watson statistic of 1.979 was significant at a .05 level of confidence, suggesting an absence of significant autocorrelation. Tolerance measures the extent to which the excluded variables at each step are independent of the included variables. As the level of correlation among the independent variables rises, tolerance tends to converge on zero. As a rule of thumb, if tolerance is less than .20 on a scale of 0 to 1.0 , a problem with multicollinearity is indicated. Here the tolerance of .463 for $\mathrm{HHI}_{b m}$ indicates the presence of a level of correlation that is appropriate for an interactive variable. Of importance in evaluating the regression results is the fact that the analysis undertaken here actually utilizes what might best be described as population data (i.e., 483 of the $500 \mathrm{~S} \& \mathrm{P} 500$ firms made up the sample) and its purpose was to explore and attempt to explain the potential consequences specific characteristics of that population, not to extrapolate.

Table 2: Step-Wise Regression Analysis

\begin{tabular}{|c|c|c|c|c|c|}
\hline \multicolumn{6}{|c|}{ Correlations } \\
\hline & $\mathbf{k}_{\mathbf{0}}$ (sig.) & $\mathrm{HHI}_{\mathrm{b}}$ (sig.) & HHI $_{\mathrm{m}}$ (sig.) & $\mathrm{HHI}_{\mathrm{mb}}$ (sig.) & \\
\hline $\mathrm{k}_{0}$ & 1.000 & .049 & -.414 & -.248 & \\
\hline $\mathrm{HHI}_{\mathrm{b}}$ & .049 & 1.000 & .152 & .733 & \\
\hline $\mathrm{HHI}_{\mathrm{m}}$ & -.414 & .152 & 1.000 & .733 & \\
\hline $\mathrm{HHI}_{\mathrm{mb}}$ & -.248 & .733 & .733 & 1.000 & \\
\hline \multicolumn{6}{|c|}{ Model Summary $\mathbf{k}_{0}=$ Dependent Variable } \\
\hline $\mathbf{R}$ & $\mathbf{R}^{2}$ & Adj. $\mathbf{R}^{2}$ & Std. Error & Sig. & DW \\
\hline $.414^{1}$ & .172 & .170 & 1.092 & .000 & \\
\hline $.422^{2}$ & .178 & .175 & 1.089 & .000 & 1.979 \\
\hline \multicolumn{6}{|c|}{ Regression Coefficients } \\
\hline Variable & \multicolumn{2}{|c|}{ Unstandardized $\beta$} & \multicolumn{3}{|c|}{ Standardized $\beta$} \\
\hline & $\beta$ & Std. Error & $\beta$ & $\mathbf{t}$ & Sig. \\
\hline (Constant) & 8.980 & .136 & & 66.240 & .000 \\
\hline $\mathrm{HHI}_{\mathrm{m}}$ & $-2.223 \mathrm{E}-04$ & .000 & -.502 & -8.265 & .000 \\
\hline $\mathrm{HHI}_{\mathrm{mb}}$ & 5.108E-09 & .000 & .120 & 1.971 & .049 \\
\hline
\end{tabular}

1, 2 Step-wise iterations

Both $\left(H H I_{m}\right)$ and $\left(H H I_{b m}\right)$ were selected for inclusion based on an $\mathrm{F}$ ratio to enter criterion of .05, yielding a regression model that accounted for 18.4 percent of the total variance with a level of statistical significance greater than .01 . Because of the parsimonious nature of the regression model, $R^{2}$ as opposed to adjusted $R^{2}$ was used to evaluate its explanatory power. 
Referring again to the hypotheses being tested here:

$\mathbf{H}_{\mathbf{1}}$ : There is not a statistically significant relationship between the level of market diversification and a firm's cost of capital.

$\mathbf{H}_{2}$ : There is not a statistically significant relationship between the interactive effect of business and market diversification and a firm's cost of capital.

The results of the step-wise regression analysis called for rejection of $\mathrm{H}_{1}$ and $\mathrm{H}_{2}$. The regression results clearly indicate the presence of a statistically significant relationship between the level of market diversification measured in terms of $H H I_{m}$ and the cost of capital measured in terms of $k_{0}$, as well as between the interaction of market and business diversification $\left(H_{H I} I_{b m}\right)$ and the cost of capital. Among S\&P 500 firms, a higher level of market diversification (a lower $\mathrm{HHI}_{m}$ ) was associated with a higher cost of capital, however, when market diversification was combined with business diversification, higher levels of market diversification in conjunction with higher levels of business diversification (a lower $\mathrm{HHI}_{b m}$ ) were associated with a lower cost of capital. The strategic implications of this result suggest that a tighter focus in selecting international markets that a firm enters and competes for will generally result in a lower cost of capital. Correspondingly, a strategy that effectively combines market with business diversification is likely to result in a lower cost of capital. Such a strategy provides an avenue to a potentially higher intrinsic and, in turn, market value. Again, these results are consistent with the findings of some of the earlier empirical research pertaining to the relationship between market diversification and various other measures of firm performance, and consistent, as well, with the sentiment of: investors who have increasingly shunned diversification and its illusory synergies in favor of strategy that emphasizes "corporate focus and a renewed emphasis on core businesses and core competencies" (Berlin, 1999). Market, or for that matter, business diversification that casts doubt in the minds of investors about management's ability to more broadly leverage the firm's core competencies, assets and technologies is likely to have the opposite effect. However, it does appear that higher combined levels of market and business diversification can produce synergies that may justify a lower cost of capital. These expectations are consistent with the resource-based theory of the firm.

Regarding the study's limitations and possible directions for future research, no attempt was made to address industry specific effects, the underlying nature of the diversification efforts of sample firms, time related changes in the cost of capital, the motives underlying the diversification efforts of the S\&P 500 firms, or various other strategic considerations such as financing and reinvestment. That the cost of capital is, to some extent, industry specific is well understood. The interactive effect of industry and diversification is less well understood and may well be deserving of future research. Based on the research undertaken here, one would expect that when viewed industry-by-industry, market diversification and the combined effect of market and business diversification would tend to share an inverse relationship with the cost of capital, with the strength of the relationship varying among industries. With respect to related versus unrelated diversification, the results of the research undertaken here would seem to suggest that related diversification, a form of diversification that investors tend to view as more limited in scope, would be likely to result in a more modest increase in the cost of capital than would a more "radical" diversification effort. The cost of capital tends to change with the passage of time, but effects of such changes tend to be generalized over all firms. Motives for diversifying tend to be both industry and firm specific, something that may be reflected in the cost of capital. For example, diversification may be motivated by market access, cost, and/or resource considerations, any one of which might be accounted for differently by investors both within and across industries. Studying these cross-effects and their impact on the cost of capital would seem to be a rich area for future research, but it was clearly beyond the scope of the research undertaken here. It is worth noting, however, that while these effects were not specifically accounted for by this study, the net interactive effect was. Finally, variations in financing and reinvestment policies among companies and within industries, combined with the level of business and/or market diversification, impact the cost of capital. However, investigating the specific effects of these interactions was also beyond the scope of the analysis undertaken here and might well be appropriate areas of consideration for future research. Nevertheless, by virtue of its cross-sectional design, this study does account for the generalized effects of such variations in financing and reinvestment policy among the S\&P 500 firms, leaving it to be explained by future research. 


\section{CONCLUSIONS}

This study examined the extent to which market diversification and the combined effect of market and business diversification tend to influence a firm's cost of capital. By focusing on the relationship between diversification and the cost of capital, the analysis addresses an area of investigation that has been virtually ignored in the diversification literature (Lamont and Polk, 2000) and, in so doing, emphasizes the importance of the cost of capital to the process of creating shareholder value.

Market diversification was viewed independently and in conjunction with business diversification, where extremes ranged from single-market/single-business to multi-market/multi-business firms. The sample consisted of 483 of the S\&P 500 firms and diversification was measured using the Herfindahl index, where the index for market diversification $\left(H H I_{m}\right)$ was derived from geographical market revenue as a percentage of total revenue and business diversification $\left(H H I_{\mathrm{b}}\right)$ was derived from business unit revenue as a percentage of total revenue. In addition to testing for the separate effect of market diversification, the interactive effect of market and business diversification $\left(H H \mathrm{I}_{\mathrm{bm}}\right)$ was also tested for. Estimates of the cost of capital for each of the S\&P 500 firms were derived from ValuePro (www.valuepro.com).

A step-wise regression analysis was conducted where market diversification and the interactive effect of market and business diversification were regressed on the cost of capital. Both variables were selected for inclusion in the regression model using an $\mathrm{F}$ ratio for entry criterion of .05 . While higher levels of market diversification tended to result in a higher cost of capital, the combined effect of higher market and business diversification resulted in a lower cost of capital. Of particular significance is the fact that higher levels of market diversification when taken alone, led to a higher cost of capital, but undertaking market diversification in association with higher levels of business diversification led to a lower cost of capital. Overall, 17.8 percent of the variance in the cost of capital was accounted for by market diversification and the interactive effect of market and business diversification, suggesting that while $H H I_{\mathrm{m}}$ and $H H I_{b m}$ appear to be significant factors influencing a firm's cost of capital, most of the variance in the cost of capital among S\&P 500 firms remains to be explained by other factors. Although the existing literature appears to account for many of these factors, it might well be worthwhile to devote attention to the interactive effects among the cost of capital and (1) industry membership and diversification, (2) related versus unrelated diversification, (3) motives for diversifying viewed in conjunction with industry and firm specific considerations, as well as (4) variations in financing and reinvestment policies among companies and within industries at different levels of business and market diversification. Regardless of the focus the research takes, the underlying importance of the cost of capital as a determinant of shareholder value would seem to justify paying additional research into how diversification affects this important value driver.

Finally, the strategy and policy implications of this analysis for both investors and managers seem clear; higher levels market diversification tend to lead to a higher cost of capital, but a strategy featuring market diversification combined with greater business diversification tends have the opposite effect. Because of this, it is entirely reasonable to expect the value of the firm to be discounted as it becomes more diversified by market but to sell at a premium if it can take advantage of the synergies that appear to come from effectively combining market with business diversification. The results of this study seem to suggest that investors prefer less market diversification to more, unless that market diversification can be successfully combined with business diversification. Put otherwise, investors appear willing to pay a premium, expressed in terms of a lower required rate of return, for a firm with more business options that can be leveraged among more international markets. These results are consistent with the resource-based theory of the firm and they are intuitively appealing.

The creation of shareholder value has become the standard by which management's performance is judged (Rappaport, 1998), consequently, anything that tends to adversely affect the firm's cost of capital is of immediate relevance for management. The results of this study clearly suggest that investors prefer less market diversification, unless market diversification can be effectively combined with business diversification. Again, the policy and strategy implications for management are clear; diversification that is not expected to earn a return on invested capital above the firm's risk-adjusted cost of capital will cause the firm's share price to be bid down even though sales, earnings and cash flow may rise. Conversely, one would expect diversification undertaken at what investors judge to 
be a reasonable cost, where synergy is likely to result from combining market and business diversification and the same effect cannot be achieved by investors acting independently, and where it is highly likely that the resulting return on invested capital will exceed the market's required rate of return, to result in an increase in the firm's market value. Otherwise, the firm is likely to see its cost of capital bid up and, unless this increase is offset by higher returns, a challenge likely to be made more difficult when diversification takes the firm away from core activities and markets where it has a competitive advantage, the underlying economic value of the firm will decline with market value likely to follow. All of this underscores the notion that the relationship among diversification, growth, costs, investment, and financing is highly complex, but investor expectations regarding the anticipated consequences of diversification are quickly and efficiently reflected through changes in the firm's cost of capital. By focusing on this important relationship between diversification and the cost of capital, this research has attempted to fill a void in the empirical literature and to encourage others to undertake related research. In addition, this analysis appears to shed new light on the mechanism by which the widely researched "diversification discount" materializes. More international diversification is not necessarily better when measured in terms of its impact on the firm's cost of capital.

\section{REFERENCES}

1. Amram, Martha and Nalin Kulatilaka(1999). Real options: Managing strategic investment in an uncertain world, Harvard Business School Press, Cambridge: MA.

2. Berger, Philip G. and Eli Ofek (1995). Diversification's effect on firm value, Journal of Financial Economics 37, 39-66.

3. Berger, Philip G. and Eli Ofek (1996). Bust-up takeovers of value-destroying diversified firms, Journal of Finance $51,1175-1200$.

4. Berger, Philip G. and Eli Ofek (1999). Causes and consequences of corporate refocusing programs, Review of Financial Studies 12, $311-345$.

5. Berlin, Mitchell (1999). Jack of all trades? Product diversification in nonfinancial firms, Business Review, Federal Reserve Bank of Philadelphia, May/June, 15-29.

6. Bhagat, Sanjai, Andrei Shleifer, and Robert Vishny (1990). Hostile takeovers in the 1980s: The return to corporate specialization, Brookings Papers on Economic Activity: Microeconomics, 1-72.

7. Bodnar, Gordon M., Joseph Weintrop, and Charles Tang (1999). Both sides of corporate diversification: The value impacts of geographic and industrial diversification, NBER Working Paper, December, http://ssrn.com/abstract=217869.

8. Campa, Jose Manuel and Simi Kedia (2002). Explaining the diversification discount, Journal of Finance 57, 1731-1762.

9. Caves, Richard E. (1971). International corporations: The industrial economics of foreign investment, Econometrica, 38, 1-27.

10. Christophe, Stephen E. (1997). Hysteresis and the value of the U.S. multinational corporation, Journal of Business 70, 435-462.

11. Christophe, Stephen E. and Ray J. Pfeiffer, Jr. (1998). The valuation of U.S. MNC international operations during the 1990s, Working Paper, George Mason University.

12. Comment, Robert and Gregg A. Jarrell (1995). Corporate focus and stock returns, Journal of Financial Economics 37, 67-87.

13. Copeland, Tom, Tim Koller, and Jack Murrin (2000). Valuation: Measuring and managing the value of companies, third edition. New York: John Wiley \& Sons, Inc.

14. Daley, Lane, Vikas Mehrotra, and Ranjini Sivakumar (1997). Corporate focus and value creation - Evidence from spinoffs, Journal of Financial Economics 45, 257-281.

15. Denis, David J., Diane K. Denis, and Keven Yost (2002). Global diversification, industrial diversification, and firm value, Journal of Finance 57, 1951-1970.

16. Dess, Gregory G., Anil Gupta, Jean-Francois Hennart, and Charles W. Hill (1995). Conducting and integrating strategy research at the international, corporate, and business levels: Issues and direction, Special Issue: Yearly Review of Management, Journal of Management, Vol. 21, No. 3, 357-393.

17. Doukas, J. and N. G. Travlos (1988). The effect of corporate multinationalism on share holders' wealth. Evidence from international acquisitions, Journal of Finance 43, 1161-1175.

18. Ehrhardt, Michael C. (2000). The search for value: Measuring the company's cost of capital, Boston: Harvard Business School Press. 
19. Elgers, P. T. and J. J. Clark (1980). Merger types and shareholder returns: Additional evidence, Financial Management 9, 66-72.

20. Errunza, V. R. and L. W. Senbet (1981). The effects of international operations on the market value of the firm: Theory and evidence, Journal of Finance 36, 401-417.

21. (1984). International corporate diversification, market valuation, and size-adjusted evidence, Journal of Finance 39, 727-743.

22. Franko, L. G. (1989). Unrelated product diversification and global corporate performance, in A. R. Neghandi and A. Savara (eds.), International Strategic Management, Lexington Books, Lexington, MA, 221-241.

23. Geringer, Michael, P. Beamish, and R. C. da Costa (1989). Diversification strategy and internationalization: Implications for performance, Strategic Management Journal, 10, 109-119.

24. Geringer, Michael J., Stephen Tallman, and David M. Olsen (2000). Product and international diversification among Japanese multinational firms, Strategic Management Journal 21, 51-80.

25. Gertner, Robert, Eric Powers, and David Scharfstein (1999). Learning about internal capital markets from corporate spinoffs, NBER working paper.

26. Goerzen, Anthony and Paul W. Beamish (2003). Geographic scope and multinational enterprise performance, Strategic Management Journal 24, 1289-1306.

27. Grant, R. M., A. P. Jammine, and H. Thomas (1988). Diversity, diversification, and profitability among British manufacturing companies 1972-1984, Academy of Management Journal 31, 771-801.

28. Hair, Joseph F., Jr., Rolph E. Andersen, and Ronald L. Tatham (1987). Multivariate data analysis, second edition, New York, Macmillan Publishing Company.

29. Harris, Milton and Artrur Raviv (1996). The capital budgeting process: Incentives and information, Journal of Finance 51, 1139-1174.

30. Herfindahl, O. C. (1950). Concentration in the steel industry, Ph.D. Dissertation, Columbia University.

31. Hitt, M. A., R. E. Hoskisson, and H. Kim (1997). International diversification: Effects on innovation and firm performance in product-diversified firms, Academy of Management Journal 40, 767-798.

32. Hubbard R. Glenn and Darius Palia (1999). A re-examination of the conglomerate merger wave in the 1960's: An internal capital markets view, Journal of Finance 54, 1131-1152.

33. Hymer, Stephen Herbert (1976). The international operations of national firms: A study of direct foreign investment, MIT Press, Cambridge: MA.

34. Iskandar-Datta, Mai and Robyn McLaughlin (2005). Global diversification: New evidence from corporate operating performance, Working Paper, retrieved from www.fma.org/chicago/papers/fmadiversity.pdf.

35. Itami, H., T. Kagono, H. Yoshihara, and A. Sakuma (1982). Diversification strategies and economic performance, Japanese Economic Studies 11, 78-110.

36. Jensen, Michael C. (1989). Eclipse of the public corporation, Harvard Business Review 67, 61-74.

37. John, Kose and Eli Ofek (1995). Asset sales and increase in focus, Journal of Financial Economics 37, $105-126$.

38. Kaplan, Steven and Michael S. Weisbach (1992). The success of acquisitions: Evidence from divestitures, Journal of Finance 47, 108-138.

39. Kim, W. C., P. Hwang, and W. P. Burgers (1989). Global diversification strategy and corporate profit performance, Strategic Management Journal 10, 275-286.

40. Kim, W. S. and E. O. Lyn (1986). Excess market value, the multinational corporation, and Tobin's q ratio, Journal of International Business Studies 17, 119-126.

41. Klein, P. G. (1997). Were the conglomerates inefficient? A reconsideration, Working Paper, Department of Economics, University of Georgia.

42. Kogut, Bruce (1983). Foreign direct investment as a sequential process, Charles P. Kindelberger and David Audresch (Eds.), The Multinational Corporations in the 1980s, MIT Press, Cambridge: MA.

43. Lang, Larry and René Stulz (1994). Tobin's Q, corporate diversification, and firm performance, Journal of Political Economy 102, 1248-1280.

44. Laeven, Luc and Ross Levine (2004). Is there a diversification discount in financial conglomerates? Working Paper, World Bank and NBER.

45. Lamont, Owen A. and Polk, Christopher K. (July 2000). Does diversification destroy value? Evidence from industry shocks, CRSP Working Paper No. 521. http://ssrn.com/abstract=236139

46. LeBaron, Dean and Lawrence Speidell (1987). Why are the parts worth more than the sum? Chop shop, a Corporate valuation model, in Lynne Browne and Eric Rosengren (eds.), The Merger Boom, Federal Reserve Bank of Boston, 78-95.

47. Levy, H. and M. Sarnat (1970). International diversification of investment portfolios, American Economic Review, 60, 668-675. 
48. Liebeskind, Julia, Tim Opler, and Donald Hatfield (1996). Corporate restructuring and the consolidation of U.S, industry, Journal of Industrial Economics 47, 53-68.

49. Lindström, Tom (2005). Resource-based view of diversification: Main concepts and comparision with other views, Working Paper, Helsinki University of Technology, retrieved from www.tuta.hut.fi/studies.

50. Markowitz, H. (1959). Portfolio selection: Efficient diversification of investments, New York: Wiley.

51. Mathur, Ike, Manohar Singh, and Kimberly C. Gleason (2004). Multinational diversification and corporate performance: Evidence from European firms, European Financial Management 10, 439-464.

52. Matsusaka, John (1993). Takeover motives during the conglomerate merger wave, Rand Journal of Economics 24 , 357-379.

53. Matsusaka, John (1996). Did tough antitrust enforcement cause the diversification of american corporations?, Journal of Financial and Quantitative Analysis 31, 283-294.

54. Maquiera, Carlos P., William L. Megginson, and Lance Nail (1998). Wealth creation versus wealth redistributions in pure stock-for-stock mergers, Journal of Financial Economics 48, 3-33.

55. Montgomery, Cynthia (1994). Corporate diversification, Journal of Economic Perspectives 8, 163-178.

56. Montgomery, Cynthia and Birger Wernerfelt (1998). Diversification, ricardian rents, and Tobin's q, Rand Journal of Economics 19, 623-632.

57. Morck, Randall, Andrei Sheifer, and Robert Vishny (1990). Do managerial objectives drive bad acquisitions?, Journal of Finance 45, 31-48.

58. Morck, Randall and Bernard Yeung (1991). Why investors value multinationality, Journal of Business 64, 165186.

59. (1997). Why investors sometimes value size and diversification: The internalization theory of synergy, Research Seminar in International Economics, School of Public Policy, University of Michigan, Discussion Paper No. 411, September 5, retrieved from http://www.spp.umich.edu//rsie/workingpapers/wp.html.

60. Peyer, Urs and Anil Shivdasani (2001). Leverage and internal capital markets: Evidence from leveraged recapitalizations, Journal of Financial Economics 57, 477-515.

61. Ramanujam, V. and P. Varadarajan (1989). Research on corporate diversification: A synthesis, Strategic Management Journal 10, 523-551.

62. Rappaport, Alfred (1998). Creating Shareholder Value, The Free Press, New York: NY.

63. (1986). Creating Shareholder Value: The New Standard for Business Performance, The Free Press, New York: NY.

64. Ravenscraft, David and Frederick Scherer (1987). Mergers, sell-offs and economic efficiency, The Brookings Institution.

65. Robins, J. A. and M. F. Wiersema (1995). A resource-based approach to the multibusiness firm: Empirical analysis of portfolio interrelationships and corporate financial performance, Strategic Management Journal 16, 277-299.

66. Rumelt, Richard (1974). Strategy, Structure, and Economic Performance, Boston, Division of Research, Harvard Business School, 1974.

(1982). Diversification strategy and profitability, Strategic Management Journal 3, 359-369.

67.

68. Servaes, Henri (1996). The value of diversification during the conglomerate merger wave, Journal of Finance 51, 1201-1225.

69. Schlingemann, Frederik P., René M, Stulz, and Ralph A. Walkling (1999). Corporate focusing and internal capital markets, NBER Working Paper 7175.

70. Schoar, Antoinette (1999). Effects of corporate diversification on productivity, Journal of Finance 57, $2379-2404$

71. Tabachnick, Barbara G. and Linda S. Fidell (2001). Using Multivariate Statistics, Fourth Edition, Boston: Allyn and Bacon.

72. Tallman, Stephen and J. T. Li (1996). The effects of international diversity and product diversity on the performance of multinational firms, Academy of Management Journal 39, 179-198.

73. Villalonga, Belen (2000). Does diversification cause the diversification discount?, Working Paper, University of California at Los Angeles, Anderson Graduate School of Management 1079, Anderson Graduate School of Management, UCLA. 